Hans-Joachim Klaus Ruff-Stahl, LtCol in the Political Directorate at the German Ministry of Defence and Asst. Professor at Embry-Riddle Aeronautical University

\title{
THE STRATEGIC ASSESSMENT MODEL (STRATAM) STUDYING AND PREVENTING STRATEGIC FAILURE
}

\section{Keywords}

Operational art, strategy, organizational failure

\begin{abstract}
The purpose of this study is to introduce the Strategic Assessment Model (STRATAM), a model designed to assist in the prevention of strategic failure. STRATAM aids firstly in the assessment of a strategy, as well as its crafting and evolution; secondly, it aims to enable and possibly streamline civil-military strategic debates on military operations. It is argued that strategic blunders in many cases result from latent organizational failures on one's own side. Therefore, STRATAM combines Clausewitz' theory of war and strategy with organizational failure theory. To demonstrate the use of this model, this paper uses Operation Cast Lead (or the Gaza War) of 2008-2009 as a case study. The paper's findings include that the ultimate reasons for strategic failure were on one hand Clausewitzian; on the other hand, the Israeli Defense Force's failure in organizational learning from a previous war two years earlier. The timely, strategic assessment and an effective civil-military debate about the effects of ongoing military operations might have prevented this failure. STRATAM would have provided the necessary language, structure, and relevance to identify actual and potential strategic failures with the goal to evolve the strategy.
\end{abstract}

\section{Introduction}

In recent decades, the West - including Israel - has not been particularly successful in winning wars. Small wars such as the 2008-2009 Israeli Operation Cast Lead have proven to be an extremely tough strategic challenge. Often, strategic failure has been attributed to the actions of an asymmetrically fighting enemy or more recently, to "reasons of complexity". Yet in contrast to this view, 
strategic failure may in fact be caused by one's own flawed organizational processes and human factors. Clausewitz' notion that "everything in strategy is very simple, but that does not mean that everything is very easy," (Clausewitz, 1976: 178) may already be read in this way: while a strategy should not be overcomplicated, human error prone and thus a set up for failure, strategic success, in turn, depends on an effective organization including leaders, who are cognizant of human factors and are able to timely assess and adapt a strategy if necessary.

So far, the impact of human and organizational factors has been thoroughly investigated and widely understood in other complex socio-technical endeavors such as aviation, but its impact on strategy has been overlooked. In military history, there are multiple and very diverse examples of organizational and human factors caused failures that have originated at the level of strategic leadership. Roughly seventy years ago, Winston Churchill observed that commanders-in-chief are surrounded by "smiling and respectful faces" (Cohen, 2003: 111) that much more prefer to communicate success stories than potential failures - even occasionally (and in most cases unintentionally) bending the truth in their interactions with strategic decision makers. Consequently, in spite of Churchill having been an avid military expert, his "errors of strategic judgment" were "all too often" induced by his "professional advisors." (Ibid.: 112)

As another example, commanders-in-chief may also discover the complete incoherence of strategy during a war. President Barack Obama discovered shortly after his election, and more than eight years into a war, that "there was no coherent strategy" (Woodward, 2010: 80) for Afghanistan, let alone "strategic goals". (Ibid.) Besides organizational inabilities to come up with a strategy and failures in communication about strategy within organizations, (Clausewitz, 1976: 149) Douglas Porch points out yet another strategic failure: offering tactical solutions to strategic problems, such as Counterinsurgency (COIN). (Few, 2010: 7)

Apart from flawed interaction and the confusion about what the more tactical and more strategic levels in warfare are, even high-level decision makers themselves contribute to strategic failure, either out of unfamiliarity with strategic thought or out of an unwillingness to think strategically. While many 
political decision makers did not attend any type of strategic leadership school, even for some well educated defense intellectuals strategy is "intellectual terrorism" and in these modern times, only "amateurs, to be sure, talk about strategy." (Corn, 2008) It seems that not only key strategic decision makers, but also entire defense organizations, including some contemporary defense intellectuals may have lost their grounding in the fundamentals of strategic thought for various reasons, effectively setting up military organizations for strategic failure.

Hence, the purpose of this paper is to present an original method to assess, adapt, and evolve a strategy based on human factors and organizational failure theories. In the view of the author, this model contributes to military and strategic studies by introducing human factors science to the realm of strategy for the first time. The model was designed in the year 2012 by the author based on analyses of recent wars within the scholarly framework of the US Air War College.

Specifically, this model is intended to firstly, enable a quick and focused study of strategic failures; secondly, it is hoped that the use of this model enables meaningful debates between strategic experts and non-experts, thus contributing to the prevention of strategic failure in ongoing campaigns. Besides the critical claim that strategic failure is more often than not caused by human factors and organizational failure, this paper argues that STRATAM is an effective means to assist in the prevention of strategic blunders.

To make this case, the theoretical framework of this study will be based on Carl von Clausewitz' theory of strategy and war, human factors concepts, and organizational theory. For this reason, the concept of strategy is viewed as a complex relationship of the war's political purpose with the ways, means, and available resources employed to achieve specific military ends. (Clausewitz, 1976: 89) Apart from this, and following Beyerchen's (1992) interpretation of Clausewitz' concept of strategy, strategic success depends at the same time on the balance of rational political decision-making with public opinion and the complexities associated with warfare - under the constraint of limited time, information, and resources.

The Lebanon War of 2006 and Operation Cast Lead of 2008/2009 will serve as a case study to demonstrate the application of STRATAM in this study. 


\section{Strategic Failure}

Besides strategy, Clausewitz' writings offer a set of various definitions for war. For one, war is "nothing but a duel on a larger scale", (Clausewitz, 1976: 75) and an "act of force to compel our enemy to do our will". (Ibid.) In another definition, he argues that war challenges strategy with a "paradoxical trinity" (ibid.: 89) consisting of emotion, reason, and chance - in modern terms more closely related to public opinion, political decision-making, and the dynamic complexity of warfare. Not to forget a fourth and probably his most famous and most misunderstood definition that "war is merely the continuation of policy by other means". (Ibid.: 87) In short, war is a "chameleon", which continuously changes its form of appearance and self-adapts to a multitude of contexts. (Ibid.: 89) It is this fickleness and unpredictability of war, which results from a violent interaction with an enemy who is not "a lifeless mass"; instead, war is a "collision of two living forces", with both sides applying strategy against each other to achieve their own goals. (Ibid.: 77)

A cursory reading of Clausewitz' theory of war may regard his views as too vague and not precise enough to aid in the crafting or assessment of a strategy. In fact, there has been recent and substantial criticism, maintaining that $\mathrm{On}$ War does not apply anymore for the "new wars" after the end of the Cold War. Critics include i.e. distinguished Israeli strategy scholar Martin van Creveld (1991), claiming that Clausewitz' theory of war is "intellectual baggage" that needs to be "thrown overboard" (van Creveld, 1991: 58), since the trinitarian view on war (which he describes as people, government, and military) has been outdated with the rise of non-state war. In his British colleague John Keegan's view, every new war stands outside of Clausewitz' framework (Keegan, 1993: 17-18) because, as Mary Kaldor explains, civilians have now become the main targets and defeating states with militaries has become history (Kaldor, 2005: 221). Very specifically, Phillip Meilinger holds Clausewitz responsible for over 3000 US casualties in Iraq (Meilinger, 2007: 139), and Tony Corn argues that believing in Clausewitz can lead to "hair rising absurdities about the Global War on Terror" (Corn, 2008).

Yet these arguments may indicate that Clausewitz' conceptual framework of war 
and strategy and in particular his close relationship to complexity theory and even postmodern thought is not be well enough understood and does in fact have considerable explanatory power for the so called "new wars". In pragmatic terms, Christopher Bassford (2011) argues that neither van Creveld nor Keegan fully comprehended On War. Bart Schuurmann makes the point that no matter who wages war, "whether state, warlord, Communist revolutionary or international terrorist organization, all entities are subject to the interplay of the forces of violence, chance, and rational purpose" (Schuurmann, 2010: 95). In short, especially the complexity of war that results from the interplay of the different actors and the non-linearity of events (Beyerchen, 1992), is one of the central points in Clausewitzian thought.

It may even be argued that contemporary complexity theory is in far reaching agreement with Clausewitz: the greater the number of interplaying actors, ideas, rules, and technologies are, the greater will be the resulting non-linear relationship between causes and effects. In this respect, both complexity theory and Clausewitz' theory of war can be understood as antipodes to modern thinking. The rational modernity claims that that for one, cause and effect relate to each other in a determinate manner; second, effects are predictable from certain events (causes); third, abstraction and simplification - and therefore the description and understanding of complex situations - is possible; hence fourth, there are predictable reactions to planned actions; finally, rationally designable solutions to wicked problems exist.

While On War may be difficult to comprehend indeed, Clausewitz' theory centers on the idea that war and strategy are highly complex phenomena caused by social interaction. Once more, Clausewitz and post-modern complexity theory agree: due to these social interactions, cause and effect do not relate computably. Instead, effects emerge from various, seemingly negligible, often unintended causes. But understanding and coping with interaction problems in sociotechnical environments is less a strategic problem than it is a human factors and organizational question. 


\section{Human factors and organizational theory apply in the operational realm}

The study of human factors and use of organizational models emerged in the 1930s with Heinrich's (1931) domino theory, followed by Charles Perrow's (1984) Normal Accident Theory (NAT) many decades later and recently the High Reliability Organization theory (HRO, Senge, 1995). These theories and models are based on the idea that blunders occur as a result from a series of preceding factors, which are set up and shaped by the leadership of an organization and the organization itself in terms of its structures and processes. The most important insight of these models for strategic problems is that these preconditions, which increase the probability of unsafe behaviors, such as inappropriate decision-making, may be preventable on the organizational level.

On the human factors side, the SHELL model provided a new look at the role of humans in a complex system since the 1970s. The name is an acronym formed by initial letters of its components Software, Hardware, Environment, and Liveware, (Skybrary, 2011) where "Software" stands for rules, policies, doctrine and "Hardware" for technology. According to this model, failure results from interaction problems between the human element ("Liveware") and the other components of the model in a VUCAD environment. The take-away from this model for the realm of war and strategy is the idea that an analysis of individual operational parts such as doctrine ("Software"), technology ("Hardware"), human resources ("Liveware"), and the operational VUCAD environment by itself will not deliver useful answers when assessing a strategy or strategic failure. Instead, the interplay between and mutual influences of these components must be evaluated.

Since the 1990s, James Reason's Swiss Cheese model (1990) successfully combined organizational models based on Heinrich's Domino Theory with human factors. In his model, the higher levels of an organization directly influence the next lower level until ultimately the act of failure occurs. Thus, failures on the strategic level will eventually manifest themselves in operational and tactical errors - either as a failed attempt to implement the strategy, or as a deviation from it. In other words, strategic failure is a latent failure, which may be dormant for a long time until one day it will directly affect the military operations on the battlefield, and thus become an active failure. Reason's model 
has since been updated by other non-linear accident models such as FRAM (Hollnagel, 2004) and STAMP (Leveson, 2004).

Until roughly 10 years ago, these models were used almost exclusively in aviation contexts. (Porter, 1964) Later, their use expanded into other areas, including the medical field, (Emslie et al. 2002) emergency response, (MacLeod, 2011) and crime prevention. (Holderstein-Holtermann, 2009) Yet since the 1990s, the notions of "accident" and "safety" have been broadened to "failure" and "absence of failure" respectively, which enabled the use of these models in the realms of business and management. (Reason, 2000) In military applications other than aviation, the question of human factors has mainly reappeared in the context of Network Centric Warfare. (NCW, NAGO, 2010, US Air Force 2006, and Australian Department of Defence, 2004).

However, the widely used organizational and human factors models of the late 1990s, such as Reason's Swiss Cheese model and others do not explain what these latent failures exactly are. (Shappell and Wiegmann, 2000) Thus, a comprehensive conceptual framework for organizational failure was still missing, which was subsequently corrected by Shappell and Wiegmann with the introduction of their Human Factors Analysis and Classification System (HFACS) in the year 2000. Today, HFACS is the most widely used model to analyze the roles that humans and organizations play in cases of organizational failure. (Stringfellow, 2010)

HFACS is in essence based on Reason's failure causation model and on the idea of linear cause-and-effect relationships in an organization. According to Margaret Stringfellow (2010: 39), "linear accident models view the occurrence of accidents as the result of a chain of events or linear sequences of failures. If one event in the proximate causal chain is prevented from occurring, the accident will not occur. Thus, hazard analyses based on linear accident models are geared towards finding sequences of failures that can lead to accidents." It is important to point out that sequences of failures may result from active or, more importantly, latent systemic failures. Active failures are noticeable events or specific human actions that directly result in an accident or a failure. Yet latent failures are dormant, but no less problematic properties of an organization setting it up for failure - if only given the right circumstances. In most cases, these 
latent failures become clearly noticeable only after an accident or failure has occurred and the subsequent investigation reveals the cause-and-effect relationships as well as the "chain of events", which led up to the failure. In short, Reason-based failure causation models seek to detect and describe the latent or dormant failures on higher, strategic levels of an organization, which may precede the actual failure on the "sharp end" of an organization, and which become only then visible in retrospect when an operational fiasco has already occurred.

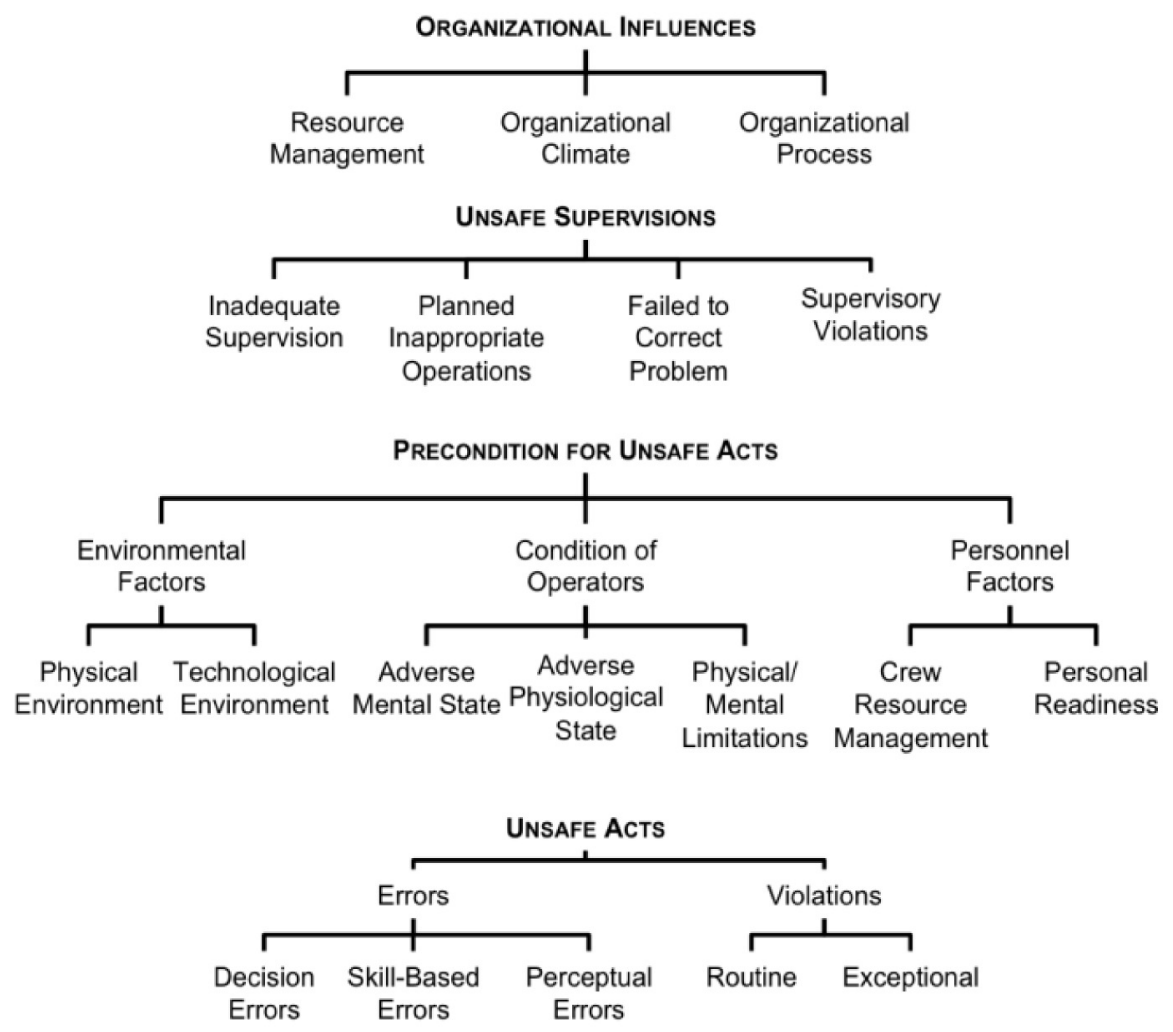

Figure 1. Human Factors Analysis and Classification System

Similar to most human factors and organizational failure and accident causation models, HFACS itself was originally intended for aviation, listing and 
structuring errors, faults, problems, and bad decisions in organizations consisting of human actors. The four levels of this model include the lowest, tactical level of "Unsafe Acts", made up of "Violations" and "Errors". According to this model, errors occur due to the influence of particular conditions, which are relevant for each different, actual situation. These influences constitute the second level in HFACS; Shappell and Wiegmann label it "Preconditions". The third level relates to operational leadership and is called "Unsafe Supervision". It consists of leadership failures such as bad planning, not correcting problems, or inadequate leadership involvement. The highest, strategic level is labeled "Organizational Influences", and includes problems of resourcing, organizational climate, and processes. The original HFACS model looks like this (retrieved from: http://www.hfacs.com/sites/default/files/HFACS-Tree_0.png).

While in a recent critique of this model, Margret Stringfellow criticizes its "too vague" and "not disjoint enough" differentiations of detailed human and organizational classifications, her criticism does not quite apply to the realm of strategy. The model's inherent vagueness and ambiguity correlates satisfactorily to, what Clausewitz describes by the term "art" (Clausewitz, 1976: 170) of war and war's "realm of uncertainty" - in other words, Stringfellow's criticism seem to make this model even more suitable for the assessment of strategy. (Ibid.: 101)

\section{STRATAM as a Synthesis of Strategic and Organizational Theory}

The Strategic Assessment Model (STRATAM) is a relatively simple model for strategic assessment, based on human factors and organizational failure theories and Clausewitz' theory of war. It is not only intended to support the processes of crafting, assessing, and evolving a strategy, but also to enable and ease civilmilitary strategic debates. Since Clausewitz' theory provides a valid framework for the assessment of strategy, an adaptation of the HFACS model for the framework of warfare becomes possible. The highest organizational level of this model corresponds to the political level, whereas the model's lowest level corresponds to the operational level - being the sharp end of a strategic organization in war. Moreover, it is the operational level where latent, strategic organizational failures translate into active and actual operational fiascos. Therefore, drawing upon Clausewitz' theory of strategy and the structural framework of HFACS, the four levels of strategic failure in STRATAM are: 1) 
Political Influences, 2) Military-Strategic Influences, 3) Preconditions for Operational Failure, and 4) Operational Failures.

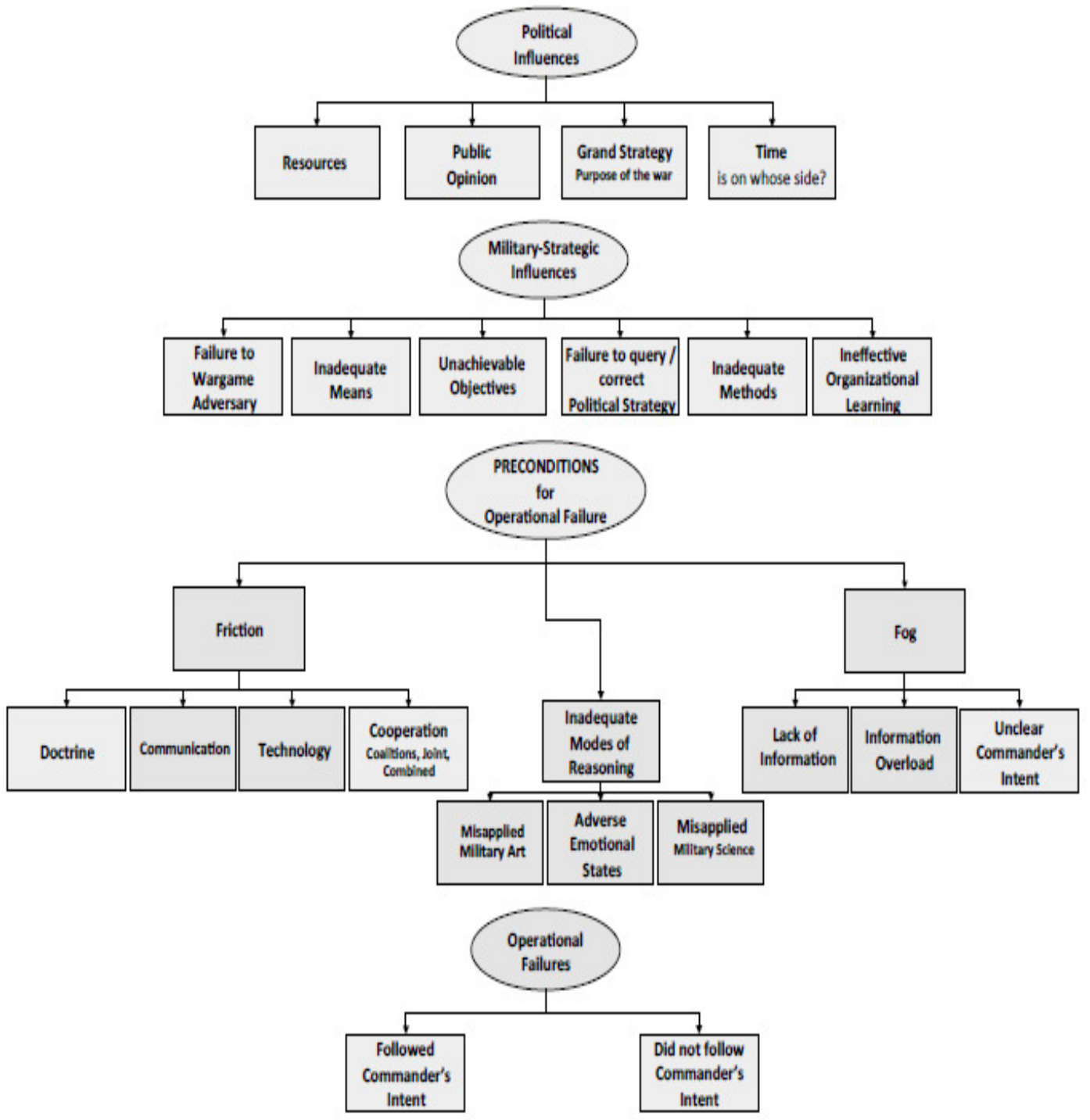

Figure 2: Strategic Analysis and Classification System (STRATAM) 
On the lowest, operational level, actions may result in kinetic or non-kinetic acts of failure and can be categorized in two alternatives: either an operational commander took action in an attempt to follow his or her commander's intent and thus the overall strategy, or conversely, the local commander chose not to follow the overall intent or strategy. More specifically, failures that have resulted after an operational commander was indeed following the strategic intent means that these type of failures fall under the "error" classification in the sense of the original HFACS model. If a failure has occurred after a commander did not follow the strategic intent, this type of failure could in theory be filed under the "violations" category in the sense of the original HFACS model. Yet in some cases, a commander may have different and valid reasons for not following the strategic intent because the situation dictates a different course of action. Thus, classifying the immediate causes for operational failure as either errors or violation would fall short because it would fail to consider the dynamic complexity of warfare.

On the next level, STRATAM takes a look at the preconditions, which may have existed and led to the local commander's irksome decisions and actions. Here, STRATAM suggests three categories, centering on Clausewitzian concepts of friction, (Clausewitz, 1976: 119) the fog of war, (ibid.: 101 and 140) and inadequate modes of reasoning. (Ibid.: 100) For Clausewitz, the modes of military reasoning in war should integrate scientific thought (what he calls mathematical or geometrical thinking as well as probability calculation) with what he calls the "art of war" and the "genius" of a commander, which relate to creativity, critical thinking and intuition. While every mode of reasoning should be applied at the right time and for the right set of circumstances to succeed, the common error, according to Clausewitz, is an over-reliance on logical-analytical reasoning.

Frictional preconditions include operational leaders' interaction problems (ibid.: 149 ) with doctrine, with their peers or subordinate commanders (in other words communication failures), and failing to adequately employ available technology. Preconditions summarized as the "fog of war" include informational problems (ibid.: 140) such as the lack of information, or data overload (ibid.: 178) as well as an unclear commander's intent. (Ibid.: 87-88 and 90-99) Inadequate modes of 
reasoning are unique to each situation (ibid.: 119) and include misapplied operational art (ibid.: 100-103, 111, and 112) or science, (ibid.: 85-86) as well as adverse emotional states. (Ibid.: 104-116) Besides Clausewitz' theory of warfare, this section of preconditions relates most closely to the operational challenge of situational awareness; a concept, which according to Mica Endsley (1995) consists of three levels: level 1, perception, regards the ability to perceive the relevant factors of a situation, level 2, comprehension, regards to an understanding of what these factors mean in terms of their impact on the possibility to achieve one's own goals. Level 3 , projection, regards to the ability to project the unfolding of events and the ability to predict what will happen next.

All preconditions for operational failure are themselves influenced by the military-strategic level. This level includes possible dormant failures such as the Clausewitzian concepts of unachievable military objectives, (Clausewitz, 1976: 80-81) inadequate means and methods, (ibid.: 143-144) failures to critically and creatively think through and wargame the adversary's behavior, (ibid.: 579-580) and the failure to query the political strategy: in the view of Eliot Cohen (2003), if the course of a war does not unfold according to plan, the interaction of the overall military commander with his or her political leaders becomes even more critical. Thus, argues Cohen, it is the duty of senior military leadership to query the strategy and, if necessary, convince political leaders to review and adapt the overall war aim and its purpose. (Clausewitz, 1976: 608-609)

The remaining military-strategic level influence, labeled ineffective organizational learning, (ibid.: 88) not only roots in organizational failure theory, but also in Clausewitz' theory of war. Both organizational theory and Clausewitz describe organizational learning as the ability to adapt to a (changing) environment. This relates back to Clausewitz' (1976: 88) imperative that "the first, the supreme, the most far-reaching act of judgment that the statesman and commander have to make is to establish by that test the kind of war on which they are embarking; neither mistaking it for, nor trying to turn it into, something that is alien to its nature".

The top level of politico-strategic influences encompasses an assessment of the "concerns of the people" as Clausewitz puts it, or public opinion, (ibid.: 89) and 
the assignment to consult the civilian government early enough in case the war might lose approval on the home front. Liddell Hart supports this view by claiming that "the people's willing spirit is often as important as to possess the more concrete forms of power" in matters of strategy and war. (Liddell Hart, 1967: 322)

The remaining categories on the level of political influences is labeled resources, in the sense of "all the resources of a nation", (ibid.) which has been introduced by Liddell Hart as a more precise definition of the term "means", which has been coined by Clausewitz for the realm of strategy, reminding the military leadership to query its political leadership about the necessary strategic and grand strategic means to achieve the military objectives, and an assessment on who's side time is on. Time, maintains Clausewitz, does not favor the potential victor.

(Clausewitz, 1976: 597-598)

Overall, the synthesis of HFACS and Clausewitz' theory of strategy form a relatively simple and easy to use model to study, assess, debate, and evolve a strategy if necessary, thus ideally preventing strategic failure. Further, the model's simple structure and plain text classifications should enable a meaningful strategic debate between strategic experts and non-experts. Hence, the following case study will illustrate the use of this model.

\section{A Case Study of Strategic Failure}

The subject of this case study is Operation Cast Lead, otherwise known as the Gaza War, which started on December 27 $7^{\text {th }}, 2008$ and ended 34 days later. Yet this war cannot be studied in isolation, and should instead be assessed in terms of lessons learned by the Israeli Defense Force from the Lebanon War two years earlier.

\section{The Lebanon War of 2006}

On July 12th, 2006, a Hezbollah commando unit kidnapped two Israeli soldiers and killed three others. Within hours, the Israeli Defense Force (IDF) started a retaliatory air campaign, intended to achieve a set of predetermined effects, which were calculated to convince the Hezbollah that their military operations would be futile and that they better stop fighting. The IDF followed its new 
concept Systemic Operational Design (SOD, Sorrels et al., 2005) a brainchild of Israeli Defense Forces brigadier general Shimon Naveh, who claims that this operational concept is entirely different to every other western approach to military operations becauseevery conventaional approach will include one or more clearly defined, ultimate goals as the outcome of a war. In contrast to this, SOD does not worry about clearly defined end states. Instead, SOD constantly tries to move toward a more favorable state. The guiding principle of SOD is the dynamic adaptation of military forces to a VUCA(D) enviornment. What the more favorable state is and what the subsequent operational actions must entail to reach it, is a leadership problem (for more information, see Sorrells at al, 2005). Critics of SOD claim that this concept is above all confusing and incomprehensible to the average officer (Kober, 2006). For Vego (2009), SOD is heavily influenced by French post-modern thinkers such as Lyotard (2006), Baudrillard (2002), and Virilio (2002), who are not only leftist, anti-capitalist, and incomprehensible, but more importantly "full of nonsense". In essence, argues Vego (2009), one cannot win a war with the views of these philosophers.

In any case, a large-scale ground invasion, including a potentially high number of friendly casualties, was regarded as unnecessary by IDF strategic command. (Sorrells et al., 2005) According to Israeli defense intellectual Amir Kulick, the general secretary of Hezbollah implied a quite different reason for the preference of air war, viewing the Israeli society as fragile and post-heroic and thus unable to bear the casualties of war. (Hezbollah vs. the IDF, 2006) Consistent with SOD, the IDF air strikes targeted command and control facilities, logistics centers, as well as transport and communication nodes - but not Hezbollah units directly. As a result, dispersed Hezbollah units were able to launch over 100 rockets per day on Israeli soil from positions that were hidden and equipped prewar. (Crooke, Alastair, and Perry, 2006) Even more critical, after a few days of heavy air strikes it became clear that both IDF operational objectives could not be achieved. Hezbollah neither released the Israeli soldiers, nor could the air strikes prevent the rocket attacks. Consequently, and in clear opposition to SOD and strategic planning, the IDF started a ground offensive - with mixed success at best. The IDF at this time specialized in counterinsurgency operations showed a considerable lack of performance when confronted with conventional operations such as armored combat and urban warfare. But the IDF's strategic 
failure occurred in a different domain of warfare.

Israeli forces were unable to shut down the al-Manar TV station, which continued to report about the heroic and successful defense of the Hezbollah fighters. At the same time, Israeli state-owned TV sharply criticized the IDF and its "idiotic military operations", while the print press in Israel criticized the military leadership, claiming that the IDF was unable to reach any of its operational goals. Moreover, after the IDF attacked Hezbollah infrastructure in one instance, causing a number of civilian casualties, the international press largely switched from supporting the IDF towards a support of the Hezbollah. As a consequence, the IDF as well as the Israeli public started to feel that the war would be lost. Finally, the war ended 34 days after it began, with a cease-fire that took effect on 14 August 2006. The two kidnapped IDF soldiers were returned dead to Israel, over 1000 Lebanese were killed, Lebanese infrastructure was severely damaged and hundreds of thousands of people on both sides were displaced. More importantly for the IDF, its result was a strategic failure for Israel.

\section{Operation Cast Lead, 2008/2009}

After thousands of rocket and mortar attacks from the Gaza-strip and hundreds of civilian casualties in Israel, the IDF attacked Hamas and other organizations within Gaza two years after the war in South Lebanon. The attacks began on December $27^{\text {th }}, 2008$ with probably the heaviest air strikes since the Six Day War in 1967. (Mittelstaedt, 2009) This time, the air campaign applied lessons learned from the Lebanon war two years earlier. Its first phase now included targeting Hamas directly, so that in next phase, IDF armored units would be able to divide the Gaza strip into two parts. In phase three, infantry units were supposed to occupy both areas. Overall, this operational sequence was planned in an effort to minimize the number of friendly casualties. (Beste et al., 2009)Three weeks later, Israeli Prime Minister Olmert announced that the objectives of the war had been achieved; yet the Gaza Strip was by this time far from fully occupied by the IDF. Three days after Prime Minister Olmert's announcement, Hamas announced a cease-fire and on the same day the IDF withdrew their forces from Gaza. Overall, Operation Cast Lead was widely regarded as the second Israeli defeat within two years. 


\section{Another Strategic Defeat with Media Weapons}

What were the strategic lessons learned from the Lebanon war two years earlier? First, the IDF would not allow the press inside the operations area; second, a Media Operations Center, similar to one operated by NATO during the Kosovo war and a similar one operated by US and coalition forces during the Iraq war in 2003 was tasked to provide the press with information regarding the war from a single point. (Bockstette et al. [ed.], 2006) By doing this, the IDF attempted to avoid another round of negative interviews with critical Israeli military personnel as had happened two years earlier. Third, the IDF hired a British company to monitor and improve the IDF's media image in preparation for and during the operation to have a better position in the battle for public opinion, both at home and abroad. (Witcher, 2009) The IDF even planned to use "the new media" to present information on all existing platforms. (Ehrenberg and Sagatz, 2009) Based on that concept, the IDF set up a YouTube channel, on which videos shot from the cockpit of fighter-bombers showed the precise destruction of Palestinian Kassam missiles that were fired from schoolyards or other public places. (Philipp, 2009) The idea was to present the images of a humane war, and an IDF that tried everything possible to avoid the unnecessary suffering of innocent people. But already on January 9, 2009, a Swiss newspaper started to realize that the IDF was not interested in what was actually and objectively happening in Gaza, but instead that the IDF's strategic priority was to subjectively influence worldwide public opinion in favor of Israel's cause. (Stadler, 2009: 16) In Germany, the Deutsche Welle cited the IDF spokesman Rutland explaining on 9 January 2009 that "media are an additional front where a war may be won or lost in many ways". (Informationskrieg um Gaza, 2009)

Overall, members of the international press quickly and widely resented what they considered undue influence and propaganda. Consequently, international media companies hired Palestinian amateur journalists to report from inside the Gaza Strip. The German newspaper die tageszeitung commented that reports from inside Gaza depended on a "handful of courageous local camera men, and a new generation of professional English-speaking Palestinian journalists". (ElGawhary, 2008: 2) These ad-hoc cameramen promptly delivered gruesome footage to an international audience as they covered an IDF mortar attack on 
January 7, which resulted in the death of 39 Palestinians, including women and children. On the following day of the international press coverage, the IDF media operations center reacted with unusual emotion, noticeably in attempt to reduce the strategic damage: IDF media officers contacted journalists and explained that it would be very important to understand that Hamas was responsible for this "heart-breaking tragedy" because its fighters fired first upon Israeli forces from a school yard. (Schmitz, 2009: 5) But the graphic images shot by the Palestinian amateur cameramen were by far more influential than Israeli press statements. Already another day later, the IDF's carefully thought out media strategy and its live video of precision air strikes had no chance anymore against "shock-images of dead bodies ripped in pieces" and "against the images of desperate parents carrying lifeless children into overcrowded hospitals in Gaza". (Brüning, 2009: 5)

While the international press (Mertins, 2008: 14) quickly realized that also their impromptu-journalists were delivering strategic propaganda rather than objective footage, the Palestinian reporters were nevertheless able to continue airing their highly influential view of the war. (St. Galler Tageblatt, 2008: 15) Moreover, Hamas began to both direct and edit footage. By January 10, 2009, Palestinian fighters started to bluntly force local cameramen to film only that what was deemed fit for Hama's own cause, such as "bleeding children" and "screaming women" (Krieg ohne Chronisten, 2008: 15) - in any case portraying Hamas as the "victim" of the IDF. In addition, merely hinting at any censorship by Hamas would have been a death sentence for the local reporter, as the group had already executed some of these amateur journalists as collaborators. In a further evolution of their media strategy to win the hearts of the international public, Hamas began to stage some of the footage. As Spiegel Online put it: "when three dead children sit next to each other on a couch, then this image is not credible." (Putz, 2009) Yet the IDF's inability to assess and change its media strategy in time had dire consequences. On January $09^{\text {th }}$, the Swiss NZZ speculates, "on the level of strategic communications, Israel will not be able to win this war". (Kommunikationskrieg bereits verloren, 2009) The Austrian journal Die Presse summed it up, one day prior to Israel's cease fire announcement: "it is war, thus emotion wins, not information”. (Grimm, 2009) 


\section{Discussion}

While the guiding idea of this paper is to introduce a model as a simple assessment tool for strategy, STRATAM is not intended as an all-encompassing investigation tool for military operations. Different individuals and organizations will always evaluate wars based on their own individual access to a diverse range of information sources. In other words, both strategy and the evaluation of it is a complex and creative process. Thus, the following discussion sets out to illustrate how this model may be applied based on the available information even in a so-called "new war", which proves to be not as anti-Clausewitzian as some defense intellectuals seem to think. Ideally, STRATAM will be used to assess ongoing military operations on a strategic level, in order to evolve the strategy in order to ultimately prevent strategic failure.

The STRATAM assessment process may start at any time after or during an operation. To start the process, an event should be identified, which has had unintended or negative consequences. In Operation Cast Lead, for example, multiple events would fall under this category and could have probably delivered promising results in terms of a strategic assessment. For the purpose of this paper, only the information provided earlier will be used. Thus, the AFP press release from January $07^{\text {th }}$ of 2009 , a report from inside Gaza, serves as the initial event for analysis, which stated that the IDF strategic communication plan had failed because of the published images of dead children. As a reminder, the AFP was among the news agencies that were locked out of the Gaza Strip by decision of the IDF. Therefore, the IDF commander who was responsible for enforcing the media lockout followed the overall commander's intent and strategic communications plan.

The next question is, why this overall commander's intent was in place - in other words, what preconditions existed that have caused the uncommented airing of this extremely biased and highly influential footage. According to STRATAM, this would be a frictional event. While the unfortunate collateral damage has had its own set of preconditions, the event of strategic importance was its media exploitation - which in turn was caused by doctrine. 
More precisely, the strategic precondition for this operational fiasco was the IDF's strategic communications doctrine. Although only little information is accessible through unclassified sources, the follow-on question would be whether the IDF had critically and creatively thought through and properly wargamed the operation (including its strategic communication plan) with enough degrees of freedom for the red and neutral side to find out how the adversary and the international press might react to being locked out. This question is insofar valid, because the lost media war contributed significantly to the IDF's failure in the Lebanon War of 2006. Thus, a further critical question about the IDF's organizational learning processes and ability (which is another category on this STRATAM level), presents itself. Moreover, it may be assumed that the strategic goal of preventing reports of strategic significance was in itself not only unachievable, but the IDF possessed neither the means, nor the methods to achieve this goal. In short, a lack of strategic thought becomes evident. The remaining subcategory on the military-strategic level asks whether the IDF commanders actually queried the strategy in an attempt to correct it, in case this strategic guidance came from the political level. As the highest, political level of STRATAM points out, failing to correct a strategy might result in the loss of a favorable public opinion, followed by the loss of support from the public for the war - which will the result in strategic failure overall.

Therefore, the ultimate reason for strategic failure was in fact essentially Clausewitzian: the loss of Israeli public support, preceded by the loss of international public support for this war. Consequently, the IDF command should have demanded a decisive change in media strategy and strategic communication policy - immediately after the first negative reports with potential significant impact on public opinion. Without public support, the grand strategic goal of continuing military operations in order to achieve the Clausewitzian goal of strategy - a more favorable peace - became unattainable. Besides the failure to adapt and change its strategic communication doctrine in time, the IDF failed to learn as a strategic organization from the war two years earlier. After the devastating strategic effects of negative media coverage in the Lebanon War of 2006, a realistic wargame could have probably prevented a similar experience of strategic failure two years later. 
Further, due to the faulty media and communications plan, the strategic objective to positively shape Israeli and international media became an unachievable goal, given the available means in particular circumstances. In the Clausewitzian sense, the IDF did not fully understand the kind of war on which they are embarking, thus mistaking this war for something that was alien to its nature. (Clausewitz, 1976: 88) This latent strategic failure became active through IDF commanders on the operational level, on the "sharp end" of the Israeli strategic organization, who locked out international media - fully in accordance with their strategic commanders' intent and the poorly thought-out and never adapted IDF strategic communications doctrine. As a result, time worked against the IDF within a matter of days.

\section{Conclusion}

In current strategic debates, failed strategies often have been explained with an inability to follow Sun Tsu's imperative to know the enemy! for various reasons. As a result, large portions of military investment and effort have been directed toward intelligence, surveillance and reconnaissance superiority. Yet Sun Tsu's other half of this imperative to know yourself!, in other words, the human factors aspect of strategy seems to have been overlooked. More precisely and to the knowledge of the author, human factors and organizational theory has been largely neglected in the study of politico-military problem solving in the complex environment of war. Thus, STRATAM was proposed to aid in the prevention of strategic blunders as a result of organizational failure. Using this model to study the case of the Gaza War of 2008/2009, it was found that Israel's strategic failure could have probably been prevented through a timely and comprehensive strategic debate across all operational levels - including the highest political decision-makers. With the use of a simple model such as STRATAM, this strategic debate could have potentially recognized and assessed the disastrous effects of the chosen communications strategy, and prompted a decisive and timely correction of it on the operational level.

Besides, STRATAM confirms the findings of contemporary organizational theory research, which argues that operational fiascos in most cases are not simply caused by external influence, by the environment, or by surprise, but 
instead are the direct result of one's own organizational failure: a functioning high reliability organization must be expected to cope with complex and unexpected situations successfully. In more abstract terms, this study illustrated the importance of organizational theory for strategy and suggested a model to measure an organization's actual performance.

Yet the political and military-strategic influences in a complex and dynamic environment such as warfare will include latent organizational failures a priori, which may a posteriori create preconditions for operational failure at the sharp end of a military organization. Hence it is the goal of STRATAM aiding strategists in the task of identifying and eliminating these latent failures before they become active and cause a military operation to fail.

In the case of the Gaza War of 2008/2009, an application of STRATAM shows that Israel's strategic failure could have probably been prevented through a timely and comprehensive strategic debate across all operational levels including the highest, political decision-makers. With the use of a model such as the one suggested in this paper, the strategic debate could have potentially led to the recognition and assessment of the disastrous effects resulting from the chosen communications strategy, and prompted a decisive and timely correction.

One limitation, however, is worth noting. While STRATAM offered usable results in the analysis of the 2008/2009 Gaza War, the model should be reassessed more often for consistency and completeness through the analysis of other recent wars such as Iraq, Afghanistan, Libya, and Syria. Yet, future work should not only focus on a reassessment of the model itself, but also on individual, latent or active failure modes, as described in each individual element of the model.

\section{References:}

Bassford, Christopher. "Review Essay on Carl von Clausewitz." Defense Analysis, June 1996.

Baudrillard, Jean. Screened Out. London: Verso, 2002.

Beste, Ralf, Clemens Hoeges, Hans Hoyng, Juliane von Mittelstaedt, Britta Sandberg, Christoph Schult, and Bernhardt Zand. "Die Straße riecht nach Tod.” Der Spiegel, 3/2009 (Januar 2009): 82-97. 
Beyerchen, Alan D. "Clausewitz, Nonlinearity and the Unpredictability of War." International Security 17, no. 3 (Winter 1992).

Bolia, Robert S., Michael A. Vidulich, W. Todd Nelson. "Unintended

Consequences of the Network-Centric Decision Making Model: Considering the Human Operator." US Air Force Research Laboratory, 2006. (accessed 09 December 2011).

http://oai.dtic.mil/oai/oai?verb=getRecord\&metadataPrefix=html\&identifier $=$ ADA444628

Brüning, C. "Während im Gazastreifen die Waffen vorübergehend ruhten, tobte der Krieg zwischen Israel und Hamas online weiter." Welt Kompakt, 8 January 2009: 5.

Clausewitz, Carl von. On War. Princeton, NJ: Princeton University Press, 1976.

Cohen, Eliot A. Supreme Command: Soldiers, Statesmen, and Leadership in Wartime. New York: Anchor Books, 2003.

Corn, Tony. "Clausewitz in Wonderland." Hoover Institution. Policy Review. September 2008. http://www.hoover.org/publications/policyreview/article/6795.

Creveld, Martin van. On Future War. London: Brassey's, 1991.

Crooke, Alastair, and Mark Perry. "How Hezbollah Defeated Israel. Part 2: Winning the Ground War." Asia Times Online. 13 October 2006. http://www.atimes.com/atimes/Middle_East/HJ13Ak01.html (accessed 9 January 2012).

Ehrenberg, Markus, and Kurt Sagatz. "Mein Youtube, mein Krieg." Der Tagesspiegel, 8 January 2009: 31.

El-Gawhary, Karim. "Angriffe fast unter Ausschluss der Medien." die tageszeitung, 30 December 2008: 2.

Emslie, Stuart, Kirstine Knox, and Martin Pickstone. Improving Patient Safety: Insights from American, Australian, and British Healthcare. Conference Proceedings, Department of Health, United Kingdom, Welmyn Garden City: ECRI Europe, 2002.

Endsley, M. R. (1995). Toward a theory of situation awareness in dynamic systems. Human Factors, 37(1), 32-64.

Few, Michael. "Conversation with Dr. Douglas Porch.” Small Wars Journal, 14 December 2010. http://smallwarsjournal.com/jrnl/art/a-conversation-withdr-douglas-porch (accessed 9 January 2012).

Grimm, Oliver. "Der Bilderkrieg kennt keine Sieger." Die Presse, 16 January 2009.

Heinrich, Herbert W., Dan Petersen, and Nestor R. Roos. Industrial Accident Prevention. New York: McGraw-Hill, 1931.

Helmreich, Robert L. "On Error Management: Lessons from Aviation." British 
Medical Journal 320 (2000): 781-185.

Helmreich, R. L., and A.C. Merritt. Culture at Work in Aviation and Medicine:

National, Organizational, and Professional Influences. Burlington, VT:

Ashgate, 1998.

High Reliability Organizing. http://high-reliability.org. (accessed 12 January 2012).

Holderstein-Holtermann, Jakob von. "A "Slice of Cheese" - A Deterrent-Based Argument for the International Criminal Court." Human Rights Review (Springer Science + Business Media), August 2009.

Hollnagel, Erik. Barriers and Accident Prevention. New York: Ashgate, 2004.

Jertz, Walter. "Militärische Informations- und Öffentlichkeitsarbeit am Beispiel:

Von der Kosovo "Operation Allied Force 1999" bis zu "Operation Iraqi

Freedom 2003". In Strategisches Informations- und

Kommunikationsmanagement, by Carsten Bockstette, Walter Jertz and

Stefan Quandt, 238-258. Bonn: Bernard\&Graefe, 2006.

Kaldor, Mary. "Elaborating the 'New War' Thesis." In Rethinking the Nature of

War, by I. Duyvesteyn and J Angstrom. New York: Frank Cass, 2005.

Keegan, John. A History of Warfare. New York: Vintage Books, 1993.

Kober, Avi. "The Second Lebanon War." Begin Sadat Center for Strategic

Studies. September 22, 2006.

http://www.biu.ac.il/SOC/besa/perspectives22.pdf.

Kulick, Amir. "Hizbollah vs. the IDF: The Operational Dimension." Strategic

Assessment 9, no. 3. Edited by Jaffe Center for Strategic Studies. Tel Aviv

University. Tel Aviv, November 2006.

Leveson, Nancy G. "A New Accident Model for Engineering Safer Systems."

Safety Science 42, no. 4 (2004): 237-270.

Liddell Hart, Basil H., Strategy. London: Faber \& Faber, 1967.

Lyotard, Jean F. Critical Evaluation in Cultural Theory. Edited by V. Taylor and G. Lambert. New York: Routledge, 2006

- The Postmodern Condition. Minneapolis, MN: The University of Minnesota Press, 1979.

MacLeod, Quinn. Managing Fireground Errors.

http://www.fireengineering.com/articles/print/volume-163/issue-

3/features/managing-fireground-errors.html (accessed 6 December 2011).

Meilinger, Phillip. "Busting the Icon: Restoring Balance to the Influence of

Clausewitz." Strategic Studies Quarterly 1 (Fall 2007).

Mertins, Silke. "Krieg ohne Chronisten." die tageszeitung, 31 December 2008: 14.

Mittelstaedt, Juliane von, Christoph Schult, Daniel Steinvorth, Bernhard Zand. Tage des Krieges, Tage des Zorns. 5 January 2009. http://www. spiegel. de/ 
spiegel/ print/ d-63344797. html (accessed 09 January 2012).

NATO. "Human Systems Integration for Network Centric Warfare." Technical Report, Reserach and Technology Organisation, NATO, 2010.

Perrow, Charles. Normal Accidents: Living with High-Risk Technologies. New York: Basic Books, 1984.

Philipp, Peter. "Informationskrieg um Gaza: Die Medien sind eine Front."

Deutsche Welle, 6 January 2009. www.dw-

world.de/popups/popup_printcontent/0,,3924354,00.html (accessed 9

January 2012).

Porter, Elias. Manpower Development: The System Training Concept. New York: Harper and Row, 1964.

Putz, Ulrike. "Gaza-Krieg - Wie die Hamas die Bilder des Krieges kontrolliert." Spiegel Online. 10 January 2009.

http://www.spiegel.de/politik/ausland/0,1518,600567,00.html (accessed 9 January 2012).

Reason, James. Human Error. Cambridge: Cambridge University Press, 1990.

Reason, James. "Human Error: Models and Management." Western Journal of Medicine 172, no. 6 (June 2000): 393-396.

-. Managing the Risks of Organizational Accidents. Burlington, VT: Ashgate, 1997.

Ritchey, Tom. Wicked Problems - Social Messes: Decision Support Modeling with Morphological Analysis. Berlin: Springer, 2011.

Ruff-Stahl, Hans-Joachim. Medienkriege. Wiesbaden: Verlag fuer Sozialwissenschaften, 2012.

Salendy, Gavriel., ed. Handbook of Human Factors and Ergonomics. Hoboken, NJ: Wiley \& Sons, 2006.

Satish, Usha, and Siegfried Streufert. "Strategic Management Simulations to Prepare for VUCAD Terrorism." Journal of Homeland Security, June 2006. http://www.homelandsecurity.org/journal/Default.aspx?oid=145\&ocat=1

Schmitz, Thorsten. "Der Kampf um die öffentliche Meinung." Süddeutsche Zeitung, 8 January 2009: 5.

Schuurmann, Bart. "Clausewitz and the 'New Wars' Scholars." Parameters, Spring 2010: 89-100.

Senge, Peter. The Fifth Discipline Fieldbook. New York: Doubleday, 1995.

Shappell, Scott A., and Douglas A. Wiegmann. The Human Factors and Classification System - HFACS. Springfield, VA, February 2000.

-. HFACS Website. HFACS Model. 2012. http://www.hfacs.com/sites/default/files/HFACS-Tree_0.png (accessed 10 January 2012).

Skybrary. ICAO SHELL Model. 2011. 
http://www.skybrary.aero/index.php/ICAO_SHELL_Model (accessed 30 October 2011).

Sorrells, William T., Glen R. Downing, Paul J. Blakesley, David W. Pendall, and Jason K. Walk. "Systemic Operational Design: An Introduction." US Army School for Advanced Military Studies, Fort Leavenworth, USA, 2005.

St. Galler Tageblatt. "Israel verhindert unabhängige Kriegsberichte." 6 January 2009: 4.

Stadler, Rainer. Neue Zürcher Zeitung. "Kommunikationskrieg bereits verloren; Israel im Gazastreifen." 9 January 2009: 16.

Stiehm, Judith H. The U.S. Army War College: Military Education in a Democracy. Temple University Press: Philadelphia, 2002.

Stringfellow, Margaret V. "Accident Analysis and Hazard Analysis for Human and Organizational Factors". PhD diss., Massachusetts Institute of Technology, 2010. http://sunnyday.mit.edu/saferworld/MaggieStringfellowDissertation.pdf.

Vego, Milan N. "A Case Against Systemic Operational Design.” Joint Forces Quarterly, 2009: 69-75.

Virilio, P. Ground Zero. New York: Verso, 2002.

Warne, Leoni, Irena Ali, Derek Bopping, Dennis Hart, and Celina Pascoe. The Network Centric Warrior: The Human Dimension of Network Centric Warfare. Edinburgh, South Australia: Australian Department of Defence, 2004.

Witcher, Timothy. "Israels Niederlage im Meinungskrieg." Agence France Press, 07 January 2009.

Woodward, Bob. Obama's Wars. Simon \& Schuster: New York, 2010. 